\title{
The water balance components of undisturbed tropical woodlands in the Brazilian cerrado
}

\author{
P. T. S. Oliveira ${ }^{1,2}$, E. Wendland ${ }^{1}$, M. A. Nearing ${ }^{2}$, R. L. Scott ${ }^{2}$, R. Rosolem ${ }^{3}$, and H. R. da Rocha ${ }^{4}$ \\ ${ }^{1}$ Department of Hydraulics and Sanitary Engineering, University of São Paulo, CxP. 359, São Carlos, SP, 13560-970, Brazil \\ ${ }^{2}$ USDA-ARS, Southwest Watershed Research Center, 2000 E. Allen Rd., Tucson, AZ 85719, USA \\ ${ }^{3}$ Queens School of Engineering, University of Bristol, Bristol, UK \\ ${ }^{4}$ Departamento de Ciências Atmosféricas, IAG, Universidade de São Paulo, Sao Paulo, Brazil
}

Correspondence to: P. T. S. Oliveira (paulotarsoms@gmail.com)

Received: 14 October 2014 - Published in Hydrol. Earth Syst. Sci. Discuss.: 21 November 2014

Revised: 28 May 2015 - Accepted: 01 June 2015 - Published: 22 June 2015

\begin{abstract}
Deforestation of the Brazilian cerrado region has caused major changes in hydrological processes. These changes in water balance components are still poorly understood but are important for making land management decisions in this region. To better understand pre-deforestation conditions, we determined the main components of the water balance for an undisturbed tropical woodland classified as "cerrado sensu stricto denso". We developed an empirical model to estimate actual evapotranspiration (ET) by using flux tower measurements and vegetation conditions inferred from the enhanced vegetation index and reference evapotranspiration. Canopy interception, throughfall, stemflow, surface runoff, and water table level were assessed from ground measurements. We used data from two cerrado sites, Pé de Gigante (PDG) and Instituto Arruda Botelho (IAB). Flux tower data from the PDG site collected from 2001 to 2003 were used to develop the empirical model to estimate ET. The other hydrological processes were measured at the field scale between 2011 and 2014 at the IAB site. The empirical model showed significant agreement $\left(R^{2}=0.73\right)$ with observed ET at the daily timescale. The average values of estimated ET at the IAB site ranged from 1.91 to $2.60 \mathrm{~mm} \mathrm{day}^{-1}$ for the dry and wet seasons, respectively. Canopy interception ranged from 4 to $20 \%$ and stemflow values were approximately $1 \%$ of the gross precipitation. The average runoff coefficient was less than $1 \%$, while cerrado deforestation has the potential to increase that amount up to 20-fold. As relatively little excess water runs off (either by surface water or groundwater), the water storage may be estimated by the difference between precipitation and evapotranspiration. Our
\end{abstract}

results provide benchmark values of water balance dynamics in the undisturbed cerrado that will be useful to evaluate past and future land-cover and land-use changes for this region.

\section{Introduction}

As global demand for agricultural products such as food, fiber, and fuel grows to unprecedented levels, the supply of available land continues to decrease, which is acting as a major driver of cropland and pasture expansion across much of the developing world (Gibbs et al., 2010; Macedo et al., 2012). Vast areas of forest and savannas in Brazil have been converted into farmland, and there is little evidence that agricultural expansion will decrease, mainly because Brazil holds a great potential for further agricultural expansion in the twenty-first century (Lapola et al., 2014).

The Amazon rainforest and Brazilian savanna (cerrado) are the most threatened biomes in Brazil (Marris, 2005). However, the high suitability of the cerrado topography and soils for mechanized agriculture, the small number and total extent of protected areas, the lack of a deforestation monitoring program, and the pressure resulting from decreasing deforestation in Amazonia indicates that the cerrado will continue to be the main region of farmland expansion in Brazil (Lapola et al., 2014). In fact, Soares-Filho et al. (2014) reported that the cerrado is the most coveted biome for agribusiness expansion in Brazil, given its $40 \pm 3$ Mha of land that could be legally deforested. 
The Brazilian cerrado, one of the richest ecoregions in the world in terms of the biodiversity (Myers et al., 2000), covers an area of $2 \mathrm{Mkm}^{2}(\sim 22 \%$ of the total area of Brazil); however, areas of remaining native vegetation represent only $51 \%$ of this total (IBAMA/MMA/UNDP, 2011). In addition to being an important ecological and agricultural region for Brazil, the cerrado is crucial to water resource dynamics of the country and includes portions of 10 of Brazil's 12 hydrographic regions (Oliveira et al., 2014). Furthermore, the largest hydroelectric plants (comprising $80 \%$ of the Brazilian energy) are on rivers in the cerrado. As savannas and forests have been associated with shifts in the location, intensity and timing of rainfall events, lengthening of the dry season and changed streamflow (Davidson et al., 2012; Spracklen et al., 2012; Wohl et al., 2012), it is clear that land-cover and land-use change promoted by the cropland and pasture expansion in this region have the potential to affect the ecosystem services and several of Brazil's important economic sectors, such as agriculture, energy production and water supply.

Although all indications are that farmland expansion will continue in the cerrado and that the land cover and land use will promote changes in water balance dynamics, few studies have been undertaken to investigate the hydrological processes at the field scale (plots or hillslope). In general, the studies on the cerrado hydroclimatic variability have been done on large areas (Loraie et al., 2011; Davidson et al., 2012; Oliveira et al., 2014). Evapotranspiration (ET) has been the most intensively studied component of the water balance at the field scale, usually based on eddy covariance methods (Vourlitis et al., 2002; Santos et al., 2003; da Rocha et al., 2009; Giambelluca et al., 2009) or by the water balance in the soil (Oliveira et al., 2005; Garcia-Montiel et al., 2008). However, other water balance components such as rainfall interception, canopy throughfall, stemflow, surface runoff, infiltration, percolation, subsurface flow and groundwater recharge are poorly understood in the cerrado due to lack of available observations.

To understand pre-deforestation conditions, the objective of this study was to determine the main components of the water balance for an undisturbed tropical woodland classified as "cerrado sensu stricto denso". We developed an empirical model to estimate actual ET by using flux tower measurements and vegetation conditions inferred from the enhanced vegetation index (EVI) and reference crop evapotranspiration (ETo). Canopy interception, throughfall, stemflow, and surface runoff were assessed from ground measurements. We used data from two cerrado sites, Pé de Gigante (PDG) and Instituto Arruda Botelho (IAB). Flux tower data from the PDG site collected from 2001 to 2003 was used to develop the empirical model to estimate ET. The other hydrological processes were measured at the field scale between 2011 and 2014 at the IAB site. A more comprehensive accounting of individual water balance components in the Brazilian cerrado ecosystem is of paramount importance for understanding hy-

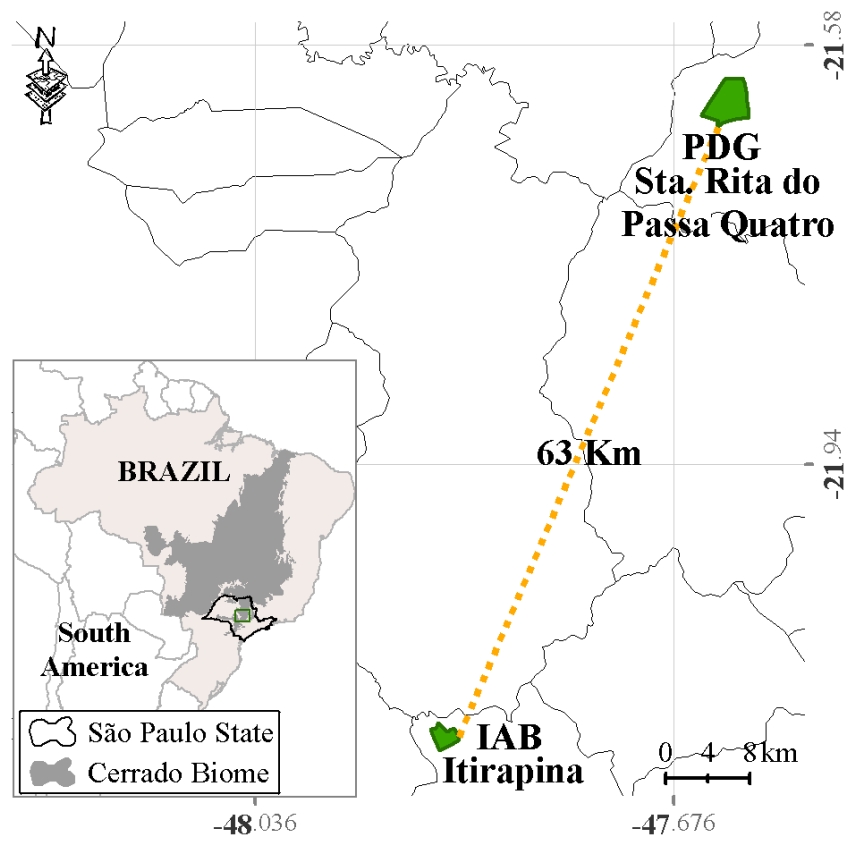

Figure 1. Location of study areas.

drological cycle shifts in the future due to possible landuse/land-cover changes.

\section{Data and methods}

\subsection{Study sites}

We developed this study using data from two cerrado sites, Pé de Gigante and Instituto Arruda Botelho, referred to throughout the text as PDG and IAB, respectively. Both sites are located in the State of São Paulo and are separated from each other by approximately $60 \mathrm{~km}$ (Fig. 1). The physiognomy of the PDG and IAB sites was classified as cerrado sensu stricto denso, which is also known as cerrado woodland, and has a characteristic arborous cover of $50-70 \%$ and trees with heights of 5-8 m (Furley, 1999). Similar soil characteristics, hydroclimatology and phenology were found between these sites (Table 1).

\subsubsection{Pé de Gigante site}

We used field measurements collected at the PDG flux tower located on a contiguous 1060 ha area of undisturbed woodland in the municipality of Santa Rita do Passa Quatro, São Paulo State (latitude $21^{\circ} 37^{\prime} \mathrm{S}$, longitude $47^{\circ} 39^{\prime} \mathrm{W}$, elevation $\sim 700 \mathrm{~m}$ ). According to the Köppen climate classification system, the climate in this area is Cwa humid subtropical, with a dry winter (April-September) and hot and rainy summer (October-March). The soil is classified in the Brazilian Soil Classification System (SiBCS) as Ortic Quartzarenic Neosol (RQo) with less than $15 \%$ clay. Net radiation $(\mathrm{Rn})$, 
Table 1. Summary of characteristics of the studied areas.

\begin{tabular}{lll}
\hline Description & PDG & IAB \\
\hline Köppen climate classification system & Cwa humid subtropical & Cwa humid subtropical \\
Average annual precipitation $(\mathrm{mm})$ and temperature $\left({ }^{\circ} \mathrm{C}\right)$ & 1478 and 21.1 & 1506 and 20.8 \\
Soil texture & sandy texture & sandy texture \\
Vegetation physiognomy & cerrado sensu stricto denso & cerrado sensu stricto denso \\
Absolute density of trees & 15278 individuals per hectare* & 13976 individuals per hectare** \\
\hline
\end{tabular}

* Reys, 2008; ** Fidelis and Godoy, 2003.

Table 2. Data collected at the IAB site.

\begin{tabular}{lll}
\hline Variable description & Sensor & Height or depth $(\mathrm{m})$ \\
\hline Temperature and relative humidity & Psychrometer HC2S3 & 9 \\
Wind speed and direction anemometer & Anemometer RM Young 05103-5 & 10 \\
Net radiation & NR-LITE2 & 10 \\
Global solar radiation & LiCor 200X & 10 \\
Precipitation & Texas TB4 & 10 \\
Atmospheric pressure & Barometer Vaisala CS106 & 2 \\
Soil moisture & EnviroScan SENTEK & $0.10,0.50,0.70,1.00,1.50$ \\
\hline
\end{tabular}

latent heat $(\mathrm{LE})$, sensible heat $(\mathrm{H})$ fluxes and ancillary meteorological data were measured at a height of $21 \mathrm{~m}$ and recorded every half-hour from January 2001 to December 2003. Details about the equipment and measurement procedures used are provided by da Rocha et al. (2002, 2009).

\subsubsection{Instituto Arruda Botelho site}

The IAB site is a 300 ha, undisturbed woodland located in the municipality of Itirapina, São Paulo State (latitude $22^{\circ} 10^{\prime} \mathrm{S}$, longitude $47^{\circ} 52^{\prime} \mathrm{W}$, elevation $780 \mathrm{~m}$ ). The soil is also classified as Ortic Quartzarenic Neosol with sandy texture in the entire profile ( $85.7 \%$ sand, $1.7 \%$ silt, and $12.6 \%$ clay) and soil bulk density of $1.7 \mathrm{~g} \mathrm{~cm}^{-3}$. We installed an $11 \mathrm{~m}$ instrumental platform to measure basic above-canopy meteorological and soil variables (Table 2). A data logger (Campbell CR1000, Logan UT, USA) sampled the weather station and soil data every $15 \mathrm{~s}$ and recorded averages on a $10 \mathrm{~min}$ basis.

\subsection{Modeling evapotranspiration}

In Brazil, there are a few flux tower sites in native cerrado vegetation. These sites are located in the states of São Paulo (da Rocha et al., 2002, 2009), Brasilia (Giambelluca et al., 2009; Miranda et al., 1997), and Mato Grosso (Vourlitis et al., 2002). There is a lack of information about ET in other cerrado regions. To fill this gap, some authors have combined vegetation indices (VI) from the remote sensing data with ground measures of ET (usually flux tower) to spatially extrapolate ET measurements over nearby regions with few or no ground data. This process consists in the use of ground measurements of ET from flux towers set in natural ecosystems to develop a best-fit equation between ET, satellite- derived VIs, ancillary remote sensing data, and ground meteorological data (Glenn et al., 2010, 2011). Such an approach has been successfully applied to determine ET in natural ecosystems such as riparian zones (Scott et al., 2008), shrublands (Nagler et al., 2007), rangeland and native prairie (Wang et al., 2007) temperate grassland, boreal forest, tundra (Mu et al., 2009) and Amazon rainforest (Juárez et al., 2008).

VIs are ratios derived from the red and near-infrared spectral reflectance and are strongly correlated with physiological processes that depend on photosynthetically active radiation absorbed by a canopy, such as transpiration and photosynthesis (Glenn et al., 2010). The normalized difference vegetation index (NDVI) and the EVI from the Moderate Resolution Imaging Spectrometer (MODIS) on the NASA Terra satellite are VIs widely used in environmental studies. However, previous studies have shown that EVI can better capture canopy structural variation, seasonal vegetation variation, land-cover variation, and biophysical variation for high-biomass vegetation (Huete et al., 2002; Juárez et al., 2008). In addition, EVI has been a better predictor of ET than NDVI (Nagler et al., 2005a, b; Glenn et al., 2007; Wang et al., 2007).

We developed an empirical relationship between ET from the PDG flux tower, MODIS EVI and ETo following the approach used by Nagler et al. (2013):

$\mathrm{ET}=\mathrm{ETo}\left[a\left(1-e^{(-\mathrm{bEVI})}\right)-c\right]$,

where $a, b$ and $c$ are fitting coefficients and $\left(1-e^{(-\mathrm{bEVI})}\right)$ is derived from the Beer-Lambert law modified to predict absorption of light by a canopy. The coefficient $c$ accounts for the fact that EVI is not zero at zero ET since bare soil has a low but positive EVI (Nagler et al., 2004, 2013). 
Daily average ET values from the PDG flux tower were computed by first filling the gaps in the $1 \mathrm{~h}$ data that were due to sensor malfunctions or bad measurements. Gaps were filled using $1 \mathrm{~h}$ averages of photosynthetically active radiation (PAR) and a 14-day look-up tables of ET values averaged over $10 \mu \mathrm{mol} \mathrm{m}^{-2} \mathrm{~s}^{-1}$ intervals (Falge et al., 2001). Then we computed daily ET averages over every 16 days to be in sync with the 16-day EVI data. We used EVI data provided by the MODIS product MOD13Q1 (http://daac.ornl. gov/MODIS/). These data are provided by National Aeronautics and Space Administration (NASA) as atmospherically and radiometrically corrected 16-day composite images with a $250 \mathrm{~m}$ spatial resolution. We obtained the MODIS EVI pixel centered on the flux tower. Daily ETo was computed according to the FAO-56 method (Allen et al., 1998) and then averaged over 16 days.

We used the parameter optimization tool genetic algorithm to fit Eq. (1), incorporating the time series of measured ET, EVI and ETo from 2001 to 2003. This process consisted of minimizing the sum of squared differences between the ET observed from eddy covariance and estimated by Eq. (1):

function $=\sum_{i=1}^{n}[\mathrm{ET}(i) \mathrm{obs}-\mathrm{ET}(i) \operatorname{sim}]^{2}$,

where ET(i)obs is the observed ET and ET(i)sim is modeled ET at time $(i)$.

For model validation, we calibrated the model using 2001 and 2002 data and then predicted ET for 2003. After this validation process we fit Eq. 1 again but this time considering the full time series that was available. The coefficient of determination $\left(R^{2}\right)$, standard deviation of differences between observed and estimated ET (SD), root mean square error (RMSE) and Student's $t$ test with a $95 \%$ confidence level were used to evaluate the significance of the linear relationship between the observed and estimated ET.

\subsection{Hydrological processes measured at the IAB site}

\subsubsection{Canopy interception}

Canopy interception (CI) was computed as the difference between the gross precipitation $\left(P_{\mathrm{g}}\right)$ and the net precipitation $\left(P_{\mathrm{n}}\right)$, where $P_{\mathrm{g}}$ is the total precipitation that fell at the top of the canopy and $P_{\mathrm{n}}$ was computed as the sum of two components, throughfall (TF) and stemflow (SF):

$\mathrm{CI}=\mathrm{P}_{\mathrm{g}}-P_{\mathrm{n}}=P_{\mathrm{g}}-(\mathrm{TF}+\mathrm{SF})$.

We measured the $P_{\mathrm{g}}$ from an automated tipping bucket rain gauge (model TB4) located above the canopy at $11 \mathrm{~m}$ height (Table 2). TF was obtained from 15 automated tipping bucket rain gauges (Davis Instruments, Hayward, CA) distributed below the cerrado canopy and randomly relocated every month during the wet season. Each rain gauge was installed considering an influence area of $10 \times 10 \mathrm{~m}$. SF was measured on 12 trees using a plastic hose wrapped around the tree trunks, sealed with neutral silicone sealant, and a covered bucket to store the water. Selected trees to be monitored were divided into two groups considering the diameter at breast height (DBH), which is the tree diameter measured at $1.30 \mathrm{~m}$ above the ground. Therefore, we monitored seven trees with $5 \mathrm{~cm}<\mathrm{DBH}<20 \mathrm{~cm}$ and five trees with DBH $>20 \mathrm{~cm}$. The volume of water in each SF collector was measured after each rainfall event that generated stemflow, totaling $42 \mathrm{SF}$ measurements during the study period. The volume of water measured from each sample tree was expressed as an equivalent volume per square meter of basal area, and then this value was multiplied by the site's basal area $\left(27.75 \mathrm{~m}^{2} \mathrm{ha}^{-1}\right)$ to compute stemflow in millimeters (Dezzeo and Chacón, 2006 and MacJannet et al., 2007). We measured $P_{\mathrm{g}}$, TF, and SF from September 2012 to July 2014.

\subsubsection{Surface runoff}

Surface runoff was measured from $100 \mathrm{~m}^{2}$ experimental plots of $5 \mathrm{~m}$ width and $20 \mathrm{~m}$ length from January 2012 to July 2014. To evaluate the cover influence on the surface runoff, experimental plots were installed under native vegetation and bare soil with steepness of approximately $0.09 \mathrm{~m} \mathrm{~m}^{-1}$. Each treatment had three replications and plots on bare soil were located about $1 \mathrm{~km}$ from the plots under undisturbed cerrado. The boundaries of the plots were made using galvanized sheets placed $30 \mathrm{~cm}$ above the soil and into the soil to a depth of $30 \mathrm{~cm}$. Surface runoff was collected in storage tanks at the end of each plot. Plots under bare soil were built with three storage tanks, each with $310 \mathrm{~L}$ capacity and two splitters of $1 / 7$; i.e., $1 / 7$ was collected in the second tank and $1 / 49$ in the third tank. In the plots under cerrado vegetation only one storage tank with a capacity of 310 liters for each plot was used to collect runoff and soil loss because of the expected lower runoff amounts from those plots.

Surface runoff was measured for each erosive rain event under the undisturbed cerrado and bare soil. Periods of rainfall were considered to be isolated events when they were separated by periods of precipitation between 0 (no rain) and $1.0 \mathrm{~mm}$ for at least $6 \mathrm{~h}$, and were classified as erosive events when $6.0 \mathrm{~mm}$ of rain fell within $15 \mathrm{~min}$ or $10.0 \mathrm{~mm}$ over a longer time period (Oliveira et al., 2013). We used this approach because in general only erosive rainfall has promoted surface runoff in the study area. A total of 65 erosive rainfall events were evaluated during the study period.

\subsubsection{Groundwater recharge}

The water table level was monitored from December 2011 to July 2014 from a well with $42 \mathrm{~m}$ in depth installed in the undisturbed cerrado. Water-table fluctuation data were measured daily from a pressure sensor (Mini-Diver model DI501, Schlumberger Limited, Houston, USA). 


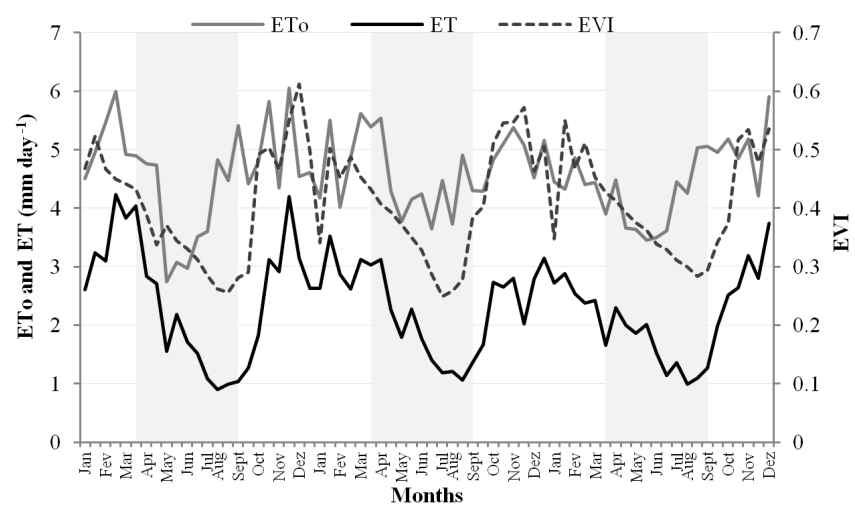

Figure 2. Seasonality of enhanced vegetation index (EVI), reference evapotranspiration (ETo) and observed actual evapotranspiration (ET) data from 2001 to 2003 at the PDG site. The grey shaded bars show the dry seasons.

\subsection{Water balance at the IAB site}

We evaluated the water balance components in the IAB site at the daily, monthly and annual timescales from January 2012 to March 2014 (Eq. 4). We used measured data of precipitation, surface runoff, and direct recharge. Evapotranspiration was estimated using the fitted equation from the EVI and reference evapotranspiration data.

$$
\frac{\mathrm{d} S}{\mathrm{~d} t}=P-\mathrm{ET}-Q-R,
$$

where $S$ is the soil water storage change with time, $P$ is precipitation, ET is evapotranspiration, $Q$ is runoff, and $R$ groundwater recharge.

\section{Results and discussion}

\subsection{Modeling ET}

The daily average ( \pm standard deviation) ETo, measured ET, and EVI at the PDG site were $4.56 \pm 0.73,2.31 \pm 0.87$, and $0.41 \pm 0.09 \mathrm{~mm} \mathrm{day}^{-1}$, respectively. We found a significant correlation between observed ET and EVI with a correlation coefficient of $0.75(p<0.0001)$. EVI showed similar seasonality that was observed for the ET and ETo during wet and dry seasons (Fig. 2). The average ET and EVI values for the wet season were $2.81 \pm 0.57$ and $0.48 \pm 0.05 \mathrm{~mm} \mathrm{day}^{-1}$, and for the dry season $1.70 \pm 0.70$ and $0.33 \pm 0.05 \mathrm{~mm} \mathrm{day}^{-1}$, respectively.

The fitted equation considering the periods of calibration, validation and full time series at 16-day averages showed good results in the ET estimates, with a coefficient of determination $\left(R^{2}\right)$ greater than 0.70 and standard deviation of differences between observed and estimated ET (SD) and RMSE of less than $0.50 \mathrm{~mm} \mathrm{day}^{-1}$ and $21 \%$, respectively
(Table 3). The final form of the fitted equation was

$\mathrm{ET}=\mathrm{ETo}\left[10.36\left(1-e^{(-12.31 \mathrm{EVI})}\right)-9.74\right]$.

The modeled values of ET estimated for the full period, wet and dry seasons $(2.30 \pm 0.76,2.81 \pm 0.31$, and $1.69 \pm 0.60 \mathrm{~mm} \mathrm{day}^{-1}$, respectively) were not significantly different $(p=0.05)$ from the observed values of ET during the same period. Furthermore, we found better values of $R^{2}, \mathrm{SD}$, and RMSE of $0.78,0.16 \mathrm{~mm} \mathrm{month}^{-1}$, and $17.07 \%$ at the monthly scale. The annual average ET observed and estimated for the $3 \mathrm{yr}$ studied (2001-2003) were 822 and $820 \mathrm{~mm} \mathrm{yr}^{-1}$, respectively, with an RMSE of $6.12 \%$. Observed ET during 2001 from the PDG site was compared previously by Ruhoff et al. (2013) with the ET estimated from the product MOD16 (Mu et al., 2011). The authors found values of $R^{2}=0.61$ and $\mathrm{RMSE}=0.46 \mathrm{~mm} \mathrm{day}^{-1}$, which were not as good as for the present study results. In a review paper about ET estimation in natural ecosystems using vegetation index methods, Glenn et al. (2010) reported values for different temporal scales ranging from 0.45 to 0.95 for the $R^{2}$ and of $10-30 \%$ for the RMSE. They concluded that the uncertainty associated with remote sensing estimates of ET is constrained by the accuracy of the ground measurements, which for the flux tower data are on the order of $10-30 \%$. Hence, the values of SD and RMSE reported in the present study are within the error bounds of the likely ground measurement errors. Our findings indicate that from this fitted equation it is possible to compute ET at 16 days and these results may be interpolated and/or summed to estimate daily, monthly or annual values.

\subsection{Canopy interception, throughfall, and stemflow}

The gross precipitation $\left(P_{\mathrm{g}}\right)$ in the IAB site during the 23month study period was $1929 \mathrm{~mm}$, where $78 \%$ of this total occurred from October to March (wet season). We found similar values of 766 and $734 \mathrm{~mm}$ for the two wet seasons studied, 2012-2013 and 2013-2014. We found a total of $333 \mathrm{~mm}$ in the dry season of 2013 (which is similar to the historical mean in this season of $307 \mathrm{~mm}$ ) and $92 \mathrm{~mm}$ between the months April and July of 2014 (Fig. 3a). The sum of TF was $1566 \mathrm{~mm}$, which corresponded to $81.2 \%$ of $P_{\mathrm{g}}$. Individual wet season TF values were 81.9 and $82.3 \%$ of $P_{\mathrm{g}}$ while total dry season $P_{\mathrm{g}}$ was $74.8 \%$. The coefficient of determination between $P_{\mathrm{g}}$ and TF was $0.99(p<0.0001)$ over the 253 rainfall days (Fig. 3b). Stemflow values (by 42 events) ranged from 0.3 to $2.7 \%$ with an average of $1.1 \%$ of $P_{\mathrm{g}}$. The greatest values of SF were found in the beginning of the wet season (October and November) and the smallest values occurred in the middle of the wet season (January and February). This suggests that there is an influence of condition of trees trunks (dry and wet) and canopy dynamics in the stemflow. Furthermore, we found greater values of SF in the trees with $5 \mathrm{~cm}<\mathrm{DBH}<20 \mathrm{~cm}\left(1.6 \%\right.$ of $\left.P_{\mathrm{g}}\right)$ than the trees with DBH $>20 \mathrm{~cm}\left(0.4 \%\right.$ of $\left.P_{\mathrm{g}}\right)$, which is consistent with results 
Table 3. Model calibration and validation results reported as the coefficient of determination $\left(R^{2}\right)$, standard deviation of differences (SD), and root mean square errors (RMSEs) for 16-day averages.

\begin{tabular}{llll}
\hline Time series & $R^{2}$ & SD $\left(\mathrm{mm} \mathrm{day}^{-1}\right)$ & RMSE (\%) \\
\hline Calibration, 2001-2002 & 0.71 & 0.50 & 20.92 \\
Validation, 2003 & 0.83 & 0.33 & 15.69 \\
Full time series, 2001-2003 & 0.73 & 0.45 & 19.53 \\
\hline
\end{tabular}

Table 4. Previous studies of throughfall (TF) and stemflow (SF) in the Brazilian cerrado. Percentages denote percent of total rainfall.

\begin{tabular}{lllll}
\hline Location & Land cover & TF (\%) & SF (\%) & Source \\
\hline Agudos, São Paulo State & cerradão & 72.7 & - & Lima and Nicolielo (1983) \\
Uberlândia, São Paulo State & cerrado sensu stricto & 89.0 & $<1$ & Lilienfein and Wilcke (2004) \\
Assis, São Paulo State & cerrado sensu stricto & 95.0 & 0.7 & Honda (2013) \\
Assis, São Paulo State & cerrado sensu stricto denso & 89.0 & 1.5 & Honda (2013) \\
Assis, São Paulo State & cerradão & 80.0 & 2.4 & Honda (2013) \\
Itirapina, São Paulo State & cerrado sensu stricto denso & 81.2 & 1.1 & Present study \\
\hline
\end{tabular}

reported by Bäse et al. (2012) for the transitional Amazoniacerrado forest.

We found only three previous studies about the interception process in the Brazilian cerrado. The values reported in the literature for TF and SF ranged from 80 to $95 \%$ of $P_{\mathrm{g}}$ and from $<1$ to $2.4 \%$ of $P_{\mathrm{g}}$, respectively (Table 4 ). In the present study the canopy interception (CI) was $17.7 \%$ of $P_{\mathrm{g}}$. Therefore, considering our findings and previous studies presented in Table 4 we can suggest that CI in the undisturbed cerrado ranges from 4 to $20 \%$ of $P_{\mathrm{g}}$. However, future studies are necessary to understand the influence of physiognomies of the cerrado in the CI processes. This region is large and complex and varies from grassland to savanna to forest (Furley, 1999; Ferreira and Huete, 2004). In addition, other characteristics such as condition of tree trunks (crooked and twisted), stand structure, canopy cover, rainfall features, and the litter interception should be better studied in specific studies of rainfall interception processes.

\subsection{Cerrado water balance}

The measured annual precipitation at the IAB site was 1248 , 1139, and $421 \mathrm{~mm}$ for 2012, 2013, and January-July of 2014, respectively. We measured 65 rainfall events that generated surface runoff during the study. The runoff coefficient for individual rainfall events (total runoff divided by total rainfall) ranged from 0.003 to 0.860 with an average value and standard deviation of $0.197 \pm 0.179$ in the bare soil plots. The highest values were found for larger, more intense rainfall events or in periods with several consecutive rainfall events, which induced high soil moisture contents and consequently greater runoff generation. Moreover, the runoff coefficient found for the bare soil plots $(\sim 20 \%)$ indicates that the soil in the study area (sandy soil) has a high infiltration capacity. Runoff coefficients ranged from 0.001 to 0.030 with an average of less than $1 \%(0.005 \pm 0.005)$ in the plots under undisturbed cerrado. Youlton (2013) studied in 2 hydrological years (2011-2012 and 2012-2013) the surface runoff using plots installed in the same experimental area as the present study and found values of 3.6-5.1\% and 2.0-5.0\% for the runoff coefficient under pasture and sugarcane, respectively. Cogo et al. (2003) reported values of runoff coefficient for soybeans and oats ranging from 2.0 to $4.0 \%$ depending to the soil tillage and management. Pasture, sugarcane and soybeans are the main cover types that have been used to replace the undisturbed cerrado lands (Loarie et al., 2011; Lapola et al., 2014). Therefore, our results indicate that the cerrado deforestation has the potential to increase surface runoff up to around 5-fold when the cerrado is replaced for pasture and croplands and up to 20 -fold for bare soil conditions.

Infiltration was calculated after subtracting interception (without accounting for the litter interception) and surface runoff from the gross precipitation. Thereby we found that $79 \%$ of the gross rainfall infiltrated into the soil. Fig. 4 shows the amount of infiltration and the volumetric water content (VWC) up to $1.5 \mathrm{~m}$ in depth. We found a rapid increase in the VWC as a function of infiltration, indicating that the sandy soil found in the IAB site promoted fast infiltration, mainly in the first meter depth of the soil profile. VWC ranged from 0.08 to 0.23 and from 0.08 to $0.17 \mathrm{~m}^{3} \mathrm{~m}^{-3}$ for 0.1 and $1.5 \mathrm{~m}$ soil depths, respectively. However, it is important to note that the root zone for trees in the cerrado is usually deep (more than $10 \mathrm{~m}$ in depth) and limited by the water table level (Oliveira et al., 2005; Garcia-Montiel et al., 2008; VillalobosVega et al., 2014). Therefore, the $1.5 \mathrm{~m}$ soil profile is not representative for evaluating the water use by vegetation, but is useful to evaluate the response for rainfall events and evaporative processes. Oliveira et al. (2005) concluded that the wa- 

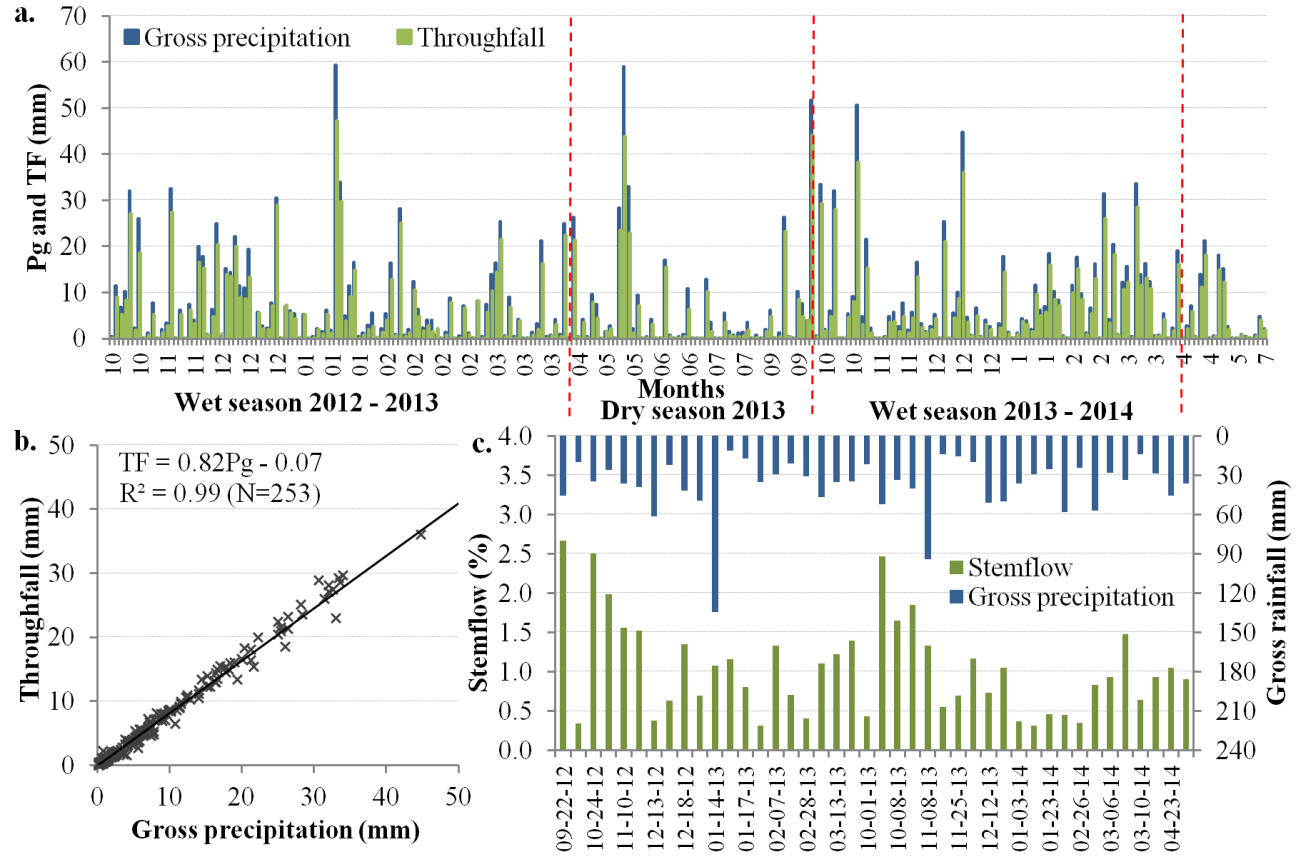

Figure 3. (a) Gross precipitation and throughfall for each rain event measured from October 2012 to July 2014. Dotted lines in red show the beginning and the end of dry seasons (April-September). (b) Scatter plot of throughfall against gross precipitation. (c) Gross precipitation and stemflow measured from September 2012 to May 2014.

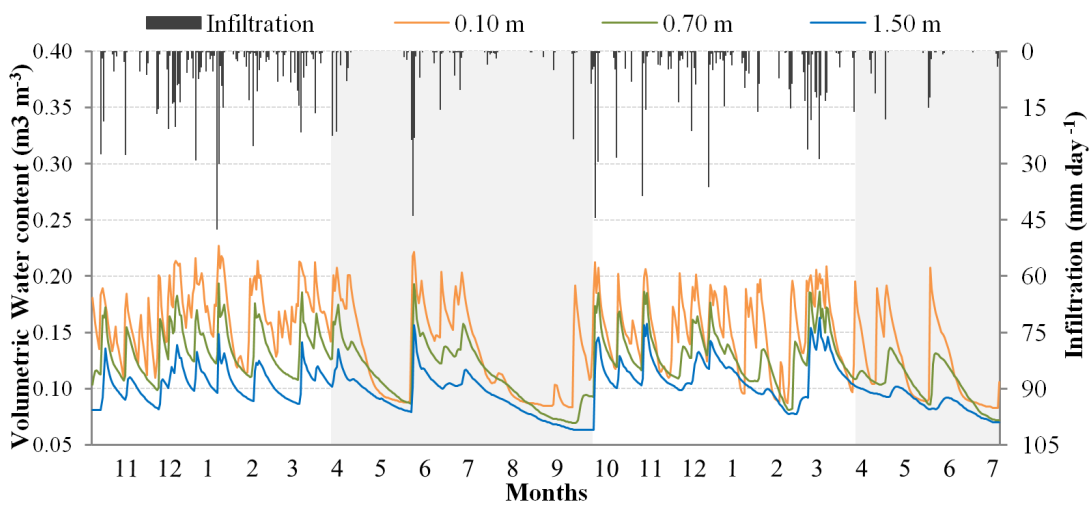

Figure 4. Estimated infiltration and volumetric water content measured at the depth of $0.10,0.70$, and $1.50 \mathrm{~m}$. Data were collected from October 2012 to July 2014. The grey shaded bars show the dry seasons.

ter stored in deep soil layers (1-4 m) provides approximately $75 \%$ of the total water used for an undisturbed cerrado classified as cerrado sensu stricto denso, the class that includes the IAB and PDG sites.

The amount of water infiltrated into the soil was not enough to elevate the water table level in the well during the study period, from December 2011 to July 2014. This was because the water table in the monitored well was approximately $35 \mathrm{~m}$ deep. In other words, there was a large distance from the soil surface to the water tables, and the amount of water that eventually reached the saturated zone was not enough to cause an immediate change in the water table level. This may happen because the flux of water reaching the groundwater zone may be in balance to groundwater outflow (water recharge is equaled the outflow). One of the first studies of groundwater dynamics in the undisturbed cerrado was conducted by Villalobos-Vega et al. (2014) from 11 monitored wells with water tables ranging from 0.18 to $15.56 \mathrm{~m}$. The authors found little water table change in regions with deep water tables (up to $15.56 \mathrm{~m}$ ), and in some wells the recharge water took up to 5 months to reach the groundwater table. They also concluded that the water table depth has a strong influence on variations in tree density and diversity, i.e., regions with deep water tables such as the IAB 


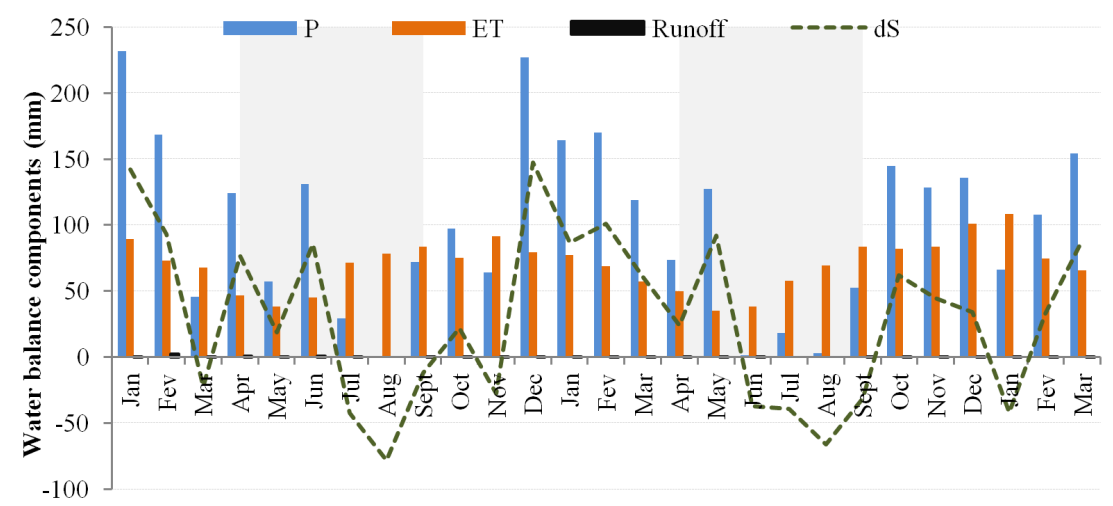

Figure 5. Water balance components at monthly scale from January 2012 to March 2014 . The grey shaded bars show the dry seasons. $P$ is precipitation, ET is evapotranspiration, and $\mathrm{d} S$ is soil water storage.

Table 5. Average evapotranspiration for PDG and IAB sites.

\begin{tabular}{|c|c|c|}
\hline Evapotranspiration (ET) & PDG & IAB \\
\hline ET full period $\left(\mathrm{mm} \mathrm{day}^{-1}\right)$ & $2.31 \pm 0.87$ & $2.30 \pm 0.67$ \\
\hline ET wet season $\left(\mathrm{mm} \mathrm{day}^{-1}\right)$ & $2.81 \pm 0.57$ & $2.60 \pm 0.38$ \\
\hline ET dry season $\left(\mathrm{mm} \mathrm{day}^{-1}\right)$ & $1.70 \pm 0.70$ & $1.91 \pm 0.60$ \\
\hline Annual ET (mm yr $\left.{ }^{-1}\right)$ & 822 & 823 \\
\hline
\end{tabular}

site $(35 \mathrm{~m})$ tend to exhibit greater tree abundance and diversity than sites with shallow water tables. Therefore, the infiltrated water in the present study was likely either extracted and transpired by the vegetation, drained by lateral subsurface flow (not measured in this studied, but probably small due to the flat topography of the site) or stored in the vadose zone.

Groundwater recharge is also affected by land-use and land-cover change (Scanlon et al., 2005; Dawes et al., 2012). We found that the undisturbed cerrado tends to provide more infiltration than areas covered with pasture and cropland. On the other hand, the cerrado vegetation has significant canopy interception and evapotranspiration that result in little groundwater recharge as compared to pasture and cropland. Using 23 monitoring wells distributed in a watershed located $5 \mathrm{~km}$ away from the IAB site, Wendland et al. (2007) showed that the groundwater recharge varies with the land cover. The authors reported values of annual recharge and water table depth, respectively, ranging from 145 to $703 \mathrm{~mm} \mathrm{yr}^{-1}(5-16 \mathrm{~m})$ in pasture, 324-694 $\mathrm{mm} \mathrm{yr}^{-1}$ $(9-22 \mathrm{~m})$ in orange citrus, and $37-48 \mathrm{~mm} \mathrm{yr}^{-1}(21 \mathrm{~m})$ in eucalyptus forests. Therefore, cerrado deforestation has the potential to change groundwater recharge dynamics.

The average values of actual ET estimated by Eq. (5) for the IAB cerrado site for the full period, wet and dry seasons were similar to that observed in the PDG site (Table 5). The annual average ET estimated for the years studied (20122013) was $823 \mathrm{~mm} \mathrm{yr}^{-1}$, which also is consistent with that found by Giambelluca et al. (2009) of $823 \mathrm{~mm} \mathrm{yr}^{-1}$ and the
$822 \mathrm{~mm} \mathrm{yr}^{-1}$ of the PDG site. Given that surface runoff was less than $1 \%$ of precipitation and groundwater recharge and subsurface lateral flow was likely small, vadose zone water storage is basically the difference between precipitation and evapotranspiration (Fig. 5).

Water deficits in the cerrado region usually happen from April to September (dry season); however, we found an atypical water decrease in the wet season (months of March and November 2012, and January 2014). Indeed, the rainfall amounts in these months were 71,56 and $39 \%$ less than in the historical mean of 1973-2013 (156, 147 and $270 \mathrm{~mm})$ observed at the climatological station from the Centro de Recursos Hídricos e Ecologia Aplicada at the University of São Paulo, located approximately $3 \mathrm{~km}$ from the study area. In addition, we note that the annual rainfall during the period of study (1248 and $1139 \mathrm{~mm}$ for 2012 and 2013, respectively) was approximately $20 \%$ less than the historical mean of $1500 \mathrm{~mm}$. The decrease of rainfall in São Paulo State in recent years has caused problems of water scarcity (Rodrigues et al., 2014).

\subsection{Broader implications for hydrological processes in the cerrado regions}

Values of water fluxes found in this study indicate that deforestation of the undisturbed cerrado lands has the potential to increase runoff and groundwater recharge, and decrease canopy interception and evapotranspiration at local or regional scales. However, the interaction of these processes over large areas may be different than that reported here because hydrological interactions and responses are dependent on the scale studied (Costa et al., 2003; Oliveira et al., 2014). Also, hydrological fluxes may vary in a typical catchment due to influences of topographic location (e.g., whether close to a stream or upland, whether in a depression or not), which affect soil water contents. Villalobos-Vega et al. (2014) concluded that water table depth has a strong influence on variations in tree density and diversity, i.e., regions with deep water tables such as the IAB site $(35 \mathrm{~m})$ tend to exhibit greater 
tree abundance and diversity than sites with a shallow water table. Therefore, if there is variation in the vegetation characteristics we can expect changes in the hydrological fluxes on different parts of a catchment. This is not an exclusive characteristic of the cerrado. In general, land around a stream (riparian areas) exhibits different hydrological fluxes than in the upland. This is the expected scenario in many catchments

Our results represent one of the first measured values for this undisturbed condition and therefore may be used as a benchmark for future studies. Future investigations are necessary to better understand the hydrological processes in the undisturbed cerrado, including the poorly studied water fluxes such as canopy interception, surface runoff, infiltration, percolation, subsurface flow and groundwater recharge. Furthermore, as the cerrado is a large biome that has different conditions of vegetation, soil types and hydrometeorology, more investigations should be conducted to cover all its conditions.

As land cover and land use of the cerrado biome have been quickly changed over recent decades with the expansion of pasture and crops (Gibbs et al., 2015), benchmark values of hydrological processes are crucial to understand pre-disturbance conditions. A better understanding of hydrological processes within the cerrado region can be used to better constrain and consequently improve hydrometeorological models. For instance, flux tower measurements at the PDG site have been successfully used to improve the understanding of the mechanisms associated with energy and carbon partitioning from several land surface models in the LBA (Large-Scale Biosphere-Atmosphere) Data Model Intercomparison Project (de Gonçalves et al., 2013), as well as for model diagnostics, and parameter identification and calibration by Rosolem et al. $(2012,2013)$. The present study can potentially expand such analyses by introducing water partitioning components such as change in soil moisture, infiltration, runoff, and canopy interception. In addition, the use of remote sensing data to estimate hydrological processes, such as the approach developed in the present study to estimate ET, is a viable alternative for evaluating the water balance spatially in the cerrado. The possibility of assessing the water balance spatially will be useful to create environmental zoning plans for this region, which seek to conserve and preserve native cerrado vegetation, and to suggest appropriate and effective land-use management practices for farmers (Oliveira et al., 2011). There is still much work to be done in the cerrado region in order to understand its unique hydrology. However, in this study we show findings that contribute toward that goal.

\section{Conclusions}

We developed an empirical model to estimate actual evapotranspiration by using flux tower measurements and vegetation conditions inferred from the enhanced vegetation index and reference evapotranspiration. We used flux tower data from the PDG site collected during 2001-2003. The empirical model developed in the present study showed a significant agreement with observed ET and better results than from the product MOD16 ET. From this empirical model it is possible to compute ET at 16 days and these results may be interpolated and/or summed to estimate daily, monthly or annual values for undisturbed cerrado areas with similar characteristics of hydroclimatology and phenology to that observed at the PDG site. Furthermore, from this approach it is possible to assess the ET for large areas of the cerrado with a good spatial and temporal resolution ( $250 \mathrm{~m}$ and 16 days); therefore, it may be useful for monitoring evapotranspiration dynamics in this region.

Canopy interception, throughfall, stemflow, surface runoff, and water table level were assessed from ground measurements at the field scale between 2011 and 2014 at the IAB site. We conclude that canopy interception may range from 4 to $20 \%$ of gross precipitation in the cerrado and that stemflow values are around $1 \%$ of gross precipitation. Our results also indicate that the average runoff coefficient was less than $1 \%$ in the plots under undisturbed cerrado and that the deforestation has the potential to increase up to 20-fold the runoff coefficient value. In addition, we did not find evidence of net groundwater table changes, possibly because the water table is at a significant depth at the IAB site, the deep rooting depth of the trees, and the study period with less rainfall than the historical mean. As only little excess water runs off (either as surface water or groundwater), the water storage may be estimated by the difference between precipitation and evapotranspiration.

Deforestation of the Brazilian cerrado has caused major changes in hydrological processes; however, these changes are still poorly understood at the field scale. Thus, understanding pre-deforestation conditions including the main components of the water balance is of paramount importance for an undisturbed cerrado. In this study, we provide benchmark values of water balance dynamics in the undisturbed cerrado that will be useful to evaluate past and future land use in different scenarios of water scarcity and climate change for this region.

Acknowledgements. This study was supported by grants from the Fundação de Amparo à Pesquisa do Estado de São Paulo - FAPESP (10/18788-5, 11/14273-3 and 12/03764-9) and the Conselho Nacional de Desenvolvimento Científico e Tecnológico - CNPq (470846/2011-9). The USDA is an equal opportunity provider and employer. We would like to thank the Arruda Botelho Institute (IAB) and São José farm, which allowed us to carry out this study in the native cerrado vegetation. Finally, we appreciate valuable comments and careful reviews from editors, and the anonymous reviewers who helped significantly to improve this manuscript.

Edited by: H. Cloke 


\section{References}

Allen, R., Pereira, L., Rais, D., Smith, M., Solomon, K., and O'Halloran, T.: Crop Evapotranspiration-Guidelines for Computing Crop Water Requirements; FAO Irrigation and Drainage Paper 56; Food and Agriculture Organization of the United Nations: Rome, Italy, 1998.

Bäse, F., Elsenbeer, H., Neill, C., and Krusche, A. V.: Differences in throughfall and net precipitation between soybean and transitional tropical forest in the southern Amazon, Brazil, Agr. Ecosyst. Environ., 159, 19-28, doi:10.1016/j.agee.2012.06.013, 2012.

Cogo, N. P., Levien, R., and Schwarz, R. A.: Perdas de solo e água por erosão hídrica influenciadas por métodos de preparo, classes de declive e níveis de fertilidade do solo, R. Bras. Ci. Solo, 27, 743-753, doi:10.1590/S0100-06832003000400019, 2003.

Costa, M. H., Botta, A., and Cardille, J. A.: Effects of largescale changes in land cover on the discharge of the Tocantins River, Southeastern Amazonia, J. Hydrol., 283, 206-217, doi:10.1016/S0022-1694(03)00267-1, 2003.

da Rocha, H. R. da, Freitas, H. C., Rosolem, R., Juárez, R. I. N., Tannus, R. N., Ligo, M. A., Cabral, O. M. R., and Dias, M. A. F. S.: Measurements of $\mathrm{CO}_{2}$ exchange over a woodland savanna (Cerrado Sensu stricto) in southeast Brasil, Biota Neotrop., 2, 111, doi:10.1590/S1676-06032002000100009, 2002.

da Rocha, H. R., Manzi, A. O., Cabral, O. M., Miller, S. D., Goulden, M. L., Saleska, S. R., Coupe, N. R., Wofsy, S. C., Borma, L. S., Artaxo, P., Vourlitis, G., Nogueira, J. S., Cardoso, F. L., Nobre, A. D., Kruijt, B., Freitas, H. C., von Randow, C., Aguiar, R. G., and Maia, J. F.: Patterns of water and heat flux across a biome gradient from tropical forest to savanna in Brazil, J. Geophys. Res., 114, 1-8, doi:10.1029/2007JG000640, 2009.

Davidson, E. A., de Araújo, A. C., Artaxo, P., Balch, J. K., Brown, I. F., Bustamante, M. M. C, Coe, M. T., DeFries, R. S., Keller, M., Longo, M., Munger, J. W., Schroeder, W., Soares-Filho, B. S., Souza, C. M., and Wofsy, S. C.: The Amazon basin in transition, Nature, 481, 321-328, doi:10.1038/nature10717, 2012.

Dawes, W., Ali, R., Varma, S., Emelyanova, I., Hodgson, G., and McFarlane, D.: Modelling the effects of climate and land cover change on groundwater recharge in south-west Western Australia, Hydrol. Earth Syst. Sci., 16, 2709-2722, doi:10.5194/hess-16-2709-2012, 2012.

de Gonçalves, L. G. G., Borak, J. S., Costa, M. H., Saleska, S. R., Baker, I., Restrepo-Coupe, N., Muza, M. N., Poulter, B., Verbeeck, H., Fisher, J. B., Arain, M. A., Arkin, P., Cestaro, B. P., Christoffersen, B., Galbraith, D., Guan, X., van den Hurk, B. J. J. M., Ichii, K., Imbuzeiro, H. M. A., Jain, A. K., Levine, N., Lu, C., Miguez-Macho, G., Roberti, D. R., Sahoo, A., Sakaguchi, K., Schaefer, K., Shi, M., Shuttleworth, W. J., Tian, H., Yang, Z. L., and Zeng, X.: Overview of the Large-Scale BiosphereAtmosphere Experiment in Amazonia Data Model Intercomparison Project (LBA-DMIP), Agric. For. Meteorol., 182-183, 111127, doi:10.1016/j.agrformet.2013.04.030, 2013.

Dezzeo, N. and Chacón, N.: Nutrient fluxes in incident rainfall, throughfall, and stemflow in adjacent primary and secondary forests of the Gran Sabana, southern Venezuela, For. Ecol. Manage., 234, 218-226, doi:10.1016/j.foreco.2006.07.003, 2006.

Falge, E., Baldocchi, D., Olson, R., Anthoni, P., Aubinet, M., Bernhofer, C., Burba, G., Ceulemans, R., Clement, R., Dolman, H., Granier, A., Gross, P., Grünwald, T., Hollinger, D., Jensen, N.-
O., Katul, G., Keronen, P., Kowalski, A., Ta Lai, C., Law, B. E., Meyers, T., Moncrieff, J., Moors, E., William Munger, J., Pilegaard, K., Rannik, Ü., Rebmann, C., Suyker, A., Tenhunen, J., Tu, K., Verma, S., Vesala, T., Wilson, K., and Wofsy, S.: Gap filling strategies for long term energy flux data sets, Agric. For. Meteorol., 107, 71-77, doi:10.1016/S0168-1923(00)00235-5, 2001.

Ferreira, L. G. and Huete, A. R.: Assessing the seasonal dynamics of the Brazilian Cerrado vegetation through the use of spectral vegetation indices, Int. J. Remote Sens., 25, 1837-1860, doi:10.1080/0143116031000101530, 2004.

Fidelis, A. T. and de Godoy, S. A. P.: Estrutura de um cerrado strico sensu na Gleba Cerrado Pé-de-Gigante, Santa Rita do Passa Quatro, SP, Acta Bot. Bras., 17, 531-539, doi:10.1590/S010233062003000400006, 2003.

Furley, P. A.: The nature and diversity of neotropical savanna vegetation with particular reference to the Brazilian cerrados, Global Ecol. Biogeogr., 8, 223-241, doi:10.1046/j.1466822X.1999.00142.x, 1999.

Garcia-Montiel, D. C., Coe, M. T., Cruz, M. P., Ferreira, J. N., da Silva, E. M., and Davidson, E. A.: Estimating Seasonal Changes in Volumetric Soil Water Content at Landscape Scales in a Savanna Ecosystem Using Two-Dimensional Resistivity Profiling, Earth Interact., 12, 1-25, doi:10.1175/2007EI238.1, 2008.

Giambelluca, T. W., Scholz, F. G., Bucci, S. J., Meinzer, F. C., Goldstein, G., Hoffmann, W. A., Franco, A. C., and Buchert, M. P.: Evapotranspiration and energy balance of Brazilian savannas with contrasting tree density, Agric. For. Meteorol., 149, 13651376, doi:10.1016/j.agrformet.2009.03.006, 2009.

Gibbs, H. K., Ruesch, A. S., Achard, F., Clayton, M. K., Holmgren, P., Ramankutty, N., and Foley, J. A.: Tropical forests were the primary sources of new agricultural land in the 1980s and 1990s, P. Natl. Acad. Sci. USA, 107, 16732-16737, doi:10.1073/pnas.0910275107, 2010.

Gibbs, H. K., Rausch, L., Munger, J., Schelly, I., Morton, D. C., Noojipady, P., Soares-Filho, B., Barreto, P., Micol, L., and Walker, N. F.: Brazil's Soy Moratorium, Science, 347, 377-378, doi:10.1126/science.aaa0181, 2015.

Glenn, E. P., Huete, A. R., Nagler, P. L., Hirschboeck, K. K., and Brown, P.: Integrating Remote Sensing and Ground Methods to Estimate Evapotranspiration, Crit. Rev. Plant Sci., 26, 139-168, doi:10.1080/07352680701402503, 2007.

Glenn, E. P., Nagler, P. L., and Huete, A. R.: Vegetation Index Methods for Estimating Evapotranspiration by Remote Sensing, Surv. Geophys., 31, 531-555, doi:10.1007/s10712-010-9102-2, 2010.

Glenn, E. P., Neale, C. M. U., Hunsaker, D. J., and Nagler, P. L.: Vegetation index-based crop coefficients to estimate evapotranspiration by remote sensing in agricultural and natural ecosystems, Hydrol. Process., 25, 4050-4062, doi:10.1002/hyp.8392, 2011.

Honda, E. A.: Repartição da água da chuva sob o dossel e umidade do solo no gradiente fisionômico da vegetação do Cerrado, Ph.D. Thesis, Universidade de São Paulo, São Carlos, SP, Brazil, 2013.

Huete, A., Didan, K., Miura, T., Rodriguez, E. P., Gao, X., and Ferreira, L. G.: Overview of the radiometric and biophysical performance of the MODIS vegetation indices, Remote Sens. Environ., 83, 195-213, doi:10.1016/S0034-4257(02)00096-2, 2002.

IBAMA/MMA/UNDP: Monitoramento do desmatamento nos biomas Brasileiros por satélite, Ministério de Meio Ambiente, Brasília, Brazil, available at: http://siscom.ibama.gov.br/ 
monitorabiomas/cerrado/index.htm (last access: 1 September 2014), 2011.

Juárez, N. R. I., Goulden, M. L., Myneni, R. B., Fu, R., Bernardes, S., and Gao, H.: An empirical approach to retrieving monthly evapotranspiration over Amazonia, Int. J. Remote Sens., 29, 7045-7063, doi:10.1080/01431160802226026, 2008.

Lapola, D. M., Martinelli, L. A., Peres, C. A., Ometto, J. P. H. B., Ferreira, M. E., Nobre, C. A., Aguiar, A. P. D., Bustamante, M. M. C., Cardoso, M. F., Costa, M. H., Joly, C. A., Leite, C. C., Moutinho, P., Sampaio, G., Strassburg, B. B. N., and Vieira, I. C. G.: Pervasive transition of the Brazilian land-use system, Nature Clim. Change, 4, 27-35, doi:10.1038/nclimate2056, 2013.

Lilienfein, J. and Wilcke, W.: Water and element input into native, agri- and silvicultural ecosystems of the Brazilian savanna, Biogeochemistry, 67, 183-212, doi:10.1023/B:BIOG.0000015279.48813.9d, 2004.

Lima, W. P. and Nicolielo, N.: Precipitação efetiva e interceptação em florestas de pinheiros tropicais e em reserva de cerradão, IPEF, 24, 43-46, 1983.

Loarie, S. R., Lobell, D. B., Asner, G. P., Mu, Q., and Field, C. B.: Direct impacts on local climate of sugarcane expansion in Brazil, Nature Clim. Change, 1, 105-109, doi:10.1038/nclimate1067, 2011.

Macedo, M. N., DeFries, R. S., Morton, D. C., Stickler, C. M., Galford, G. L., and Shimabukuro, Y. E.: Decoupling of deforestation and soy production in the southern Amazon during the late 2000s, P. Natl. Acad. Sci. USA, 109, 1341-1346, doi:10.1073/pnas.1111374109, 2012.

Marris, E.: Conservation in Brazil: The forgotten ecosystem, Nature, 437, 944-945, doi:10.1038/437944a, 2005.

Miranda, A. C., Miranda, H. S., Lloyd, J., Grace, J., Francey, R. J., Mcintyre, J. A., Meir, P., Riggan, P., Lockwood, R., and Brass, J.: Fluxes of carbon, water and energy over Brazilian cerrado: an analysis using eddy covariance and stable isotopes, Plant. Cell Environ., 20, 315-328, 1997.

Mu, Q., Jones, L. A., Kimball, J. S., McDonald, K. C., and Running, S. W.: Satellite assessment of land surface evapotranspiration for the pan-Arctic domain, Water Resour. Res., 45, 1-20, doi:10.1029/2008WR007189, 2009.

Mu, Q., Zhao, M., and Running, S. W.: Improvements to a MODIS global terrestrial evapotranspiration algorithm, Remote Sens. Environ., 115, 1781-1800, doi:10.1016/j.rse.2011.02.019, 2011.

Myers, N., Mittermeier, R. A., Mittermeier, C. G., da Fonseca, G. A. B., and Kent, J.: Biodiversity hotspots for conservation priorities, Nature, 403, 853-858, doi:10.1038/35002501, 2000.

Nagler, P. L., Glenn, E. P., Lewis Thompson, T., and Huete, A.: Leaf area index and normalized difference vegetation index as predictors of canopy characteristics and light interception by riparian species on the Lower Colorado River, Agr. Forest Meteorol., 125, 1-17, doi:10.1016/j.agrformet.2004.03.008, 2004.

Nagler, P. L., Scott, R. L., Westenburg, C., Cleverly, J. R., Glenn, E. P., and Huete, A. R.: Evapotranspiration on western U.S. rivers estimated using the Enhanced Vegetation Index from MODIS and data from eddy covariance and Bowen ratio flux towers, Remote Sens. Environ., 97, 337-351, doi:10.1016/j.rse.2005.05.011, 2005a.

Nagler, P. L., Cleverly, J., Glenn, E., Lampkin, D., Huete, A., and Wan, Z.: Predicting riparian evapotranspiration from MODIS vegetation indices and meteorological data, Remote Sens. Environ., 94, 17-30, doi:10.1016/j.rse.2004.08.009, 2005 b.

Nagler, P. L., Glenn, E. P., Kim, H., Emmerich, W., Scott, R. L., Huxman, T. E., and Huete, A. R.: Relationship between evapotranspiration and precipitation pulses in a semiarid rangeland estimated by moisture flux towers and MODIS vegetation indices, J. Arid Environ., 70, 443-462, doi:10.1016/j.jaridenv.2006.12.026, 2007.

Nagler, P., Glenn, E., Nguyen, U., Scott, R., and Doody, T.: Estimating Riparian and Agricultural Actual Evapotranspiration by Reference Evapotranspiration and MODIS Enhanced Vegetation Index, Remote Sens., 5, 3849-3871, doi:10.3390/rs5083849, 2013.

Oliveira, P. T. S., Alves Sobrinho, T., Rodrigues, D. B. B., and Panachuki, E.: Erosion risk mapping applied to environmental zoning, Water Resour. Manage., 25, 1021-1036, doi:10.1007/s11269-010-9739-0, 2011.

Oliveira, P. T. S., Nearing, M. A., Moran, M. S., Goodrich, D. C., Wendland, E., and Gupta, H. V.: Trends in water balance components across the Brazilian Cerrado, Water Resour. Res., 50, 7100-7114, doi:10.1002/2013WR015202, 2014.

Oliveira, P. T. S., Wendland, E., and Nearing, M. A.: Rainfall erosivity in Brazil: A review, Catena, 100, 139-147, doi:10.1016/j.catena.2012.08.006, 2013.

Oliveira, R. S., Bezerra, L., Davidson, E. A., Pinto, F., Klink, C. A., Nepstad, D. C., and Moreira, A.: Deep root function in soil water dynamics in cerrado savannas of central Brazil, Funct. Ecol., 19, 574-581, doi:10.1111/j.1365-2435.2005.01003.x, 2005.

Reys, P. A. N.: Estrutura e fenologia da vegetação de borda e interior em um fragmento de cerrado sensu stricto no sudeste do Brasil (Itirapina, São Paulo), Ph.D. Thesis, Universidade Estadual Paulista, Rio Claro, SP, Brazil, 2008.

Rodrigues, D. B. B., Gupta, H. V., Serrat-Capdevila, A., Oliveira, P. T. S, Mario Mendiondo, E., Maddock, T., and Mahmoud, M.: Contrasting American and Brazilian Systems for Water Allocation and Transfers, J. Water Res. Pl.-Asce, 141, 04014087 , doi:10.1061/(ASCE)WR.1943-5452.0000483, 2014.

Rosolem, R., Gupta, H. V., Shuttleworth, W. J., Zeng, X., and de Gonçalves, L. G. G.: A fully multiple-criteria implementation of the Sobol/ method for parameter sensitivity analysis, J. Geophys. Res., 117, D07103, doi:10.1029/2011JD016355, 2012.

Rosolem, R., Gupta, H. V., Shuttleworth, W. J., de Gonçalves, L. G. G. and Zeng, X.: Towards a comprehensive approach to parameter estimation in land surface parameterization schemes, Hydrol. Process., 27, 2075-2097, doi:10.1002/hyp.9362, 2013.

Ruhoff, A. L., Paz, A. R., Aragao, L. E. O. C., Mu, Q., Malhi, Y., Collischonn, W., Rocha, H. R., and Running, S. W.: Assessment of the MODIS global evapotranspiration algorithm using eddy covariance measurements and hydrological modelling in the Rio Grande basin, Hydrol. Sci. J., 58, 1658-1676, doi:10.1080/02626667.2013.837578, 2013.

Santos, A. J. B., Silva, G. T. D. A., Miranda, H. S., Miranda, A. C., and Lloyd, J.: Effects of fire on surface carbon, energy and water vapour fluxes over campo sujo savanna in central Brazil, Funct. Ecol., 17, 711-719, doi:10.1111/j.13652435.2003.00790.x, 2003.

Scanlon, B. R., Reedy, R. C., Stonestrom, D. A., Prudic, D. E., and Dennehy, K. F.: Impact of land use and land cover change on groundwater recharge and quality in the southwestern 
US, Global Change Biol., 11, 1577-1593, doi:10.1111/j.13652486.2005.01026.x, 2005.

Scott, R. L., Cable, W. L., Huxman, T. E., Nagler, P. L., Hernandez, M., and Goodrich, D. C.: Multiyear riparian evapotranspiration and groundwater use for a semiarid watershed, J. Arid Environ., 72, 1232-1246, doi:10.1016/j.jaridenv.2008.01.001, 2008.

Soares-Filho, B., Rajao, R., Macedo, M., Carneiro, A., Costa, W., Coe, M., Rodrigues, H., and Alencar, A.: Cracking Brazil's Forest Code, Science, 344, 363-364, doi:10.1126/science.1246663, 2014.

Spracklen, D. V., Arnold, S. R., and Taylor, C. M.: Observations of increased tropical rainfall preceded by air passage over forests, Nature, 489, 282-285, doi:10.1038/nature11390, 2012.

Villalobos-Vega, R., Salazar, A., Miralles-Wilhelm, F., Haridasan, M., Franco, A. C., and Goldstein, G.: Do groundwater dynamics drive spatial patterns of tree density and diversity in Neotropical savannas?, J. Veg. Sci., 25, 1465-1473, doi:10.1111/jvs.12194, 2014.

Vourlitis, G. L., Filho, N. P., Hayashi, M. M. S., Nogueira, J. S., Caseiro, F. T., and Campelo Jr., J. H.: Seasonal variations in the evapotranspiration of a transitional tropical forest of Mato Grosso, Brazil, Water Resour. Res., 38, 1-11, doi:10.1029/2000WR000122, 2002.
Wang, K., Wang, P., Li, Z., Cribb, M., and Sparrow, M.: A simple method to estimate actual evapotranspiration from a combination of net radiation, vegetation index, and temperature, J. Geophys. Res., 112, 1-14, doi:10.1029/2006JD008351, 2007.

Wendland, E., Barreto, C., and Gomes, L. H.: Water balance in the Guarani Aquifer outcrop zone based on hydrogeologic monitoring, J. Hydrol., 342, 261-269, doi:10.1016/j.jhydrol.2007.05.033, 2007.

Wohl, E., Barros, A., Brunsell, N., Chappell, N. A., Coe, M., Giambelluca, T., Goldsmith, S., Harmon, R., Hendrickx, J. M. H., Juvik, J., McDonnell, J., and Ogden, F.: The hydrology of the humid tropics, Nat. Clim. Change, 655-662, doi:10.1038/nclimate1556, 2012.

Youlton, C.: Quantificação experimental da alteração no balanço hidríco e erosão em um neossolo quartzarênico devido à substituição de pastagem por cana-de-açúcar, Ph.D. Thesis, Universidade de São Paulo, São Carlos, SP, Brazil, 2013. 